\title{
Relevance of Contractors' Prequalification Criteria to Time Performance of Civil Engineering Project
}

\author{
Ologunagba Mulikat Modupe, Akinmusire Adeleye Ola* \\ Department of Quantity Surveying, Faculty of Environmental Studies, Rufus Giwa Polytechnic, Owo, Nigeria \\ Email address: \\ ologunagbamodupe@yahoo.com (O. M. Modupe), laolu_ade@yahoo.com (A. A. Ola) \\ *Corresponding author
}

\section{To cite this article:}

Ologunagba Mulikat Modupe, Akinmusire Adeleye Ola. Relevance of Contractors' Prequalification Criteria to Time Performance of Civil Engineering Project. American Journal of Civil Engineering. Vol. 4, No. 5, 2016, pp. 225-232. doi: 10.11648/j.ajce.20160405.13

Received: June 27, 2016; Accepted: July 11, 2016; Published: July 28, 2016

\begin{abstract}
Civil engineering project completion within predetermined time schedule is usually the desire of the client and every other stakeholder. This has been a mirage because project in this case often fails to meet time target as a result of challenges emanating from its various peculiar characteristics. Civil engineering project completion within estimated time target can be achieved by adopting appropriate contractors' selection criteria. This research therefore reflected Quantity Surveyors' and Civil/Structural Engineers' perception on the relevance of contractors' prequalification criteria to time performance of civil engineering project. The purpose was to determine the impact of contractors' selection criteria on time performance of civil engineering project, revealed the contractor prequalification criteria impacting most on time performance of civil engineering project. The primary data used were obtained from construction professionals in consulting, client and contracting organizations engaging in both private and public projects through a well designed questionnaire. Regression analysis and Karl Pearson's coefficient of correlation were employed to evaluate the impact as well as relationship between contractors' prequalification criteria and time performance of civil engineering project. Contractors' prequalification criteria had both positive and negative relationship with time performance of civil engineering project at varying degree of significance. Also, contractors' prequalification criteria significantly impact on and differently predict time performance of civil engineering project. Therefore, prioritizing reputation and past performance as well as strict adherence to the impact order of the set of criteria for contractors' prequalification listed in this study would lead to achievement of civil engineering project that meet time target.
\end{abstract}

Keywords: Contractor, Prequalification, Contractors' Prequalification Criteria, Time Performance, Civil Engineering Project, Relationship, Relevance, Impact

\section{Introduction}

Construction projects obviously encompassed building, civil engineering and industrial engineering works, which often pass through three distinct stages of conception, designing and construction [1]. In the construction industry, selecting the most suitable contractor to handle the delivery of a project in accordance with predetermined quality standard, time and cost, depends on project type, nature, magnitude and time available for project execution. As a branch of the construction industry, [2] regarded civil engineering construction as a unique and special sector of the construction industry. Similarly, civil engineering was opined to be the first engineering activity, its products form the basis for human activities such as living, working, exchanging and communicating [3]. These civil engineering products were found to be in form of structures and buildings, designed and supervised by civil engineers. Having attested to the uniqueness of civil engineering projects, they differ from other construction project categories in terms of type, nature, complexity and resource requirements [4 - 6]. Evidently, contractor to handle the delivery of construction project normally pass through screening and selected based on a number of selection criteria [7 - 9]. The criteria usually adopted include past performance, business location, technical capability, financial soundness, resources, quality assurance among others [8]; [10] and [9]. The study carried 
out by [11] indicated that civil engineering project involve dealing with nature, large-scale construction activities, complex structures and takes longer time to achieve. In view of this, [12] opined that realization of civil engineering projects require planning, organizing, coordinating and controlling. It identified complexity as a major reason why civil engineering project often face a number of challenges that usually affect its completion within estimated time.

Furthermore, selected contractor is expected to successfully deliver project within a predetermined time for the project. Contrarily, [13] submitted that time overrun was peculiar to and often occur in construction projects even in the global world. According to [14 -16], construction project often fail to meet time target thereby contributing to the low performance rating ascribed to Nigeria construction industry. The research result indicated in $[9,14,16]$ listed time among the major parameters for judging the performance of construction project. According to [12] and [17], performance of civil engineering project in terms of preestimated time can be affected by delays and project characteristics, making it to experience time overrun. This was identified as a major cause of financial loss to client and contractor as well as disputes and adversarial relationship between project stakeholders [18]. Moreover, [19] observed that civil engineering contractors frequently encounter antimorale boosting factors that mostly affect time performance of civil engineering project. Consequently, civil engineering project failure in terms of timely project completion is a persistent major challenge in the Nigeria construction industry despite the screening exercise usually carried out in order to select the contractor to handle project delivery. Previous research work, which tried to establish the relevance of contractors' prequalification criteria to time performance, was one-sided. For instance, [9] focused on building and housing construction aspect of the construction industry [9]. In view of this, it was imperative to carry out this study in other to examine the relevance of contractors' prequalification criteria to time performance relative to civil engineering project. It essentially revealed the contractors' prequalification criteria that influence time performance of civil engineering project thereby forming a basis for choosing civil engineering project contractor when timely project completion was most important. This study serves as a tool to eliminating the likelihood of adopting inappropriate contractors' prequalification criteria by civil engineering project stakeholders when other construction project performance measurement yardsticks compete with time performance.

\section{Literature Review}

\subsection{Essence of Nigeria Construction Industry}

Nigeria construction industry, like any other country of the world, made impact on the development of the nation by contributing significantly to her economic growth [20]. It opined that construction industry contribute about $70 \%$ to the fixed capital formation of Nigeria showing the extent to which it impacts on the gross domestic product of the nation. According to [21], the health of the economy of any country depends on the performance of the construction industry. Hence, [20] ascribed the economic growth and well-being of a nation to the performance of the construction industry. Apart from buildings and infrastructures provision, Nigeria construction industry provides jobs for different classes of people comprising construction professionals (architects, quantity surveyors and engineers), contractors (main and subcontractors), suppliers as well as manual labourers employed by contractors [20]. Stressing the importance of the construction industry, [10] submitted that human activities, society and national economy need construction for living, working, social and manufacturing purposes. The task of providing basic infrastructural facilities for people was admitted as solely that of the construction industry. Hence, social and economic lives of people were found as dependent on the product of the construction industry. However, civil engineering project forms the basis for which infrastructural facilities are provided for the people. According to [2], civil engineering industry produces diverse civil engineering project that play crucial role in meeting infrastructural needs of the people. On the other hand, [22] posited that construction industry was considerably large containing obvious organizations of various sizes engaging in different forms of construction ranging from maintenance through repair/rehabilitation to new construction. Activities in the construction industry require active participation of its participants comprising client, Quantity Surveyors, Architects, Engineers (relating to construction) and contractors (main contractors, subcontractors and suppliers) as revealed in [23]. The task of construction product delivery within estimated time was believed to be that of project stakeholders (client, consultants and contractor). Therefore, [14] was of the opinion that most construction projects usually experience unexpected delays due to faulty designs and poor contract administration in addition to construction project's peculiar uncertainties.

\subsection{Time as Project Performance Indicator}

Completion within stipulated period of time was identified as one of the primary objectives of construction projects [13] and [15]. According to [20], construction project's time refers to the estimated period within which the project will start and finish. On the other hand, research result cited in [20], depicted that construction project time can be estimated in days/weeks indicating the starting and completion time of the project. The contribution of [24] referred to construction project as a collection of interrelated activities requiring time, men and materials (or money). These activities were said to be identifiable, measurable, and costable including discrete lowest level element of work which must be performed during the course of a project so as to achieve the project's mission [25]. However, time was admitted as one of the terms of agreement between the client and the contractor, forming part of the contract document signed by the parties 
[18]. This conferred a high degree of importance on time. Hence, it became a vital efficiency indicator as far as construction project is concerned making it crucial to construction project stakeholders (client, consultant and contractor) according to [16] and [20]. These studies emphasised the need to complete a project on or before expiration of the time limit for the project.

Customarily, construction project duration was opined to be fixed before commencement of work. It must include the period within which the project must be completed including handing over [16]. Unfortunately, construction project still experience unexpected delay and untimely delivery. The work of [18] attributed difficulty in completing construction project within predetermined time to its unique nature, improper planning, and poor management of construction time. Supporting this view, [20] ascribed construction time failure to the uncertainties usually experienced by project at construction stage. These uncertainties may arise from a number of sources. These include performance of the parties, available resources, environmental conditions, involvement of other parties, and contractual relations. The 1994 Lutham report cited in [16] indicated that clients in the construction industry were always anxious to get their projects completed on schedule. Regrettably, this was found to be rarely achieved [20]. Based on this, [26] and [27] regarded time variance as an important construction project time performance measurement tool. Furthermore, construction time can be determined using programming tools such as bar charts, network based scheduling, and sequential activities [24]. Consequently, it was suggested that construction project time be estimated based on the current practices carried out in an organized manner under the normal prevailing conditions at the places of execution according to [25]. Having fixed project duration, [28] deemed it fit to monitor the time throughout the design and construction stages. To achieve this, [6] suggested a detailed work schedule showing all the activities involved in the project together with their corresponding duration. Hence, scholars posited that every construction project is expected to be completed within the budgeted time frame. Failure to achieve construction project on time was attributed to project characteristics, procurement method, project team performance, client's representation's characteristics, design team characteristics, contractor's characteristics and external conditions as revealed in research result cited in [29].

According to [20], the extent to which construction project met time target determines its effectiveness. Consequently, time performance of construction projects can be judged based on a number of factors, such as completion within predetermined project duration, average delay experienced in regular payments, time expended on implementation of variation orders and time needed to rectify defects that occurred during construction and defect liability period [29]. The length of time expended on site preparation and average delay experienced in claims approval were listed among the factors for judging time performance of construction project. The effect of these factors was identified to include frequent time overrun experienced by construction projects leading to client's dissatisfaction [20]. Consequently, the speed with which a construction project was delivered has been considered to be of paramount importance [6]. Therefore, [20] suggested adequate preparation by project stakeholders towards ensuring total compliance with contract terms of agreement and timely granting of extension of time when necessary. The study identified proper management of construction time as an antidote to claim for extension of time and its attendant liquidated and ascertained damages claims.

\subsection{Contractors' Prequalification and Selection Criteria}

Prequalification of contractors mean different thing to different people. For instance, [30] defined contractors' prequalification as the process of assessing the suitability of contractors by either the client or his representatives based on a number of predetermined criteria. On the other hand, [31] opined that prequalification was a pretendering exercise designed to determine qualified contractors from among those who signified intention to participate in the process of contractor selection. Moreover, [7] and [32] viewed prequalification as the stage in the process of contractor selection where contractors are being examined and assessed prior to their invitation to tender for a proposed project. The purpose of contractor's prequalification, as revealed in literatures, was not only to evaluate contractors' competence or ability but to prune down the number of potential bidders [31]. Apart from this, it was believed that contractors' prequalification was designed to determine those who would be eligible to move to the next stage in the contractor selection process thereby eliminating unqualified contractors at an early stage in the selection process [30]. The bulk of contractors' selection activities were observed to be done during prequalification because of the considerably large number of contractors that may be involved with more information/data/documents to treat by the prequalifier. Furthermore, [7, 32, 33] agreed that prequalifying contractors offers client and consultants the opportunity to prune down the number of prospective contractors in order to come out with a standing list of equally capable contractors that can satisfactorily deliver the project at hand. Thus, prevents unqualified bidders from participating in the tender stage of contractor selection process [34]. Hence, prequalified contractors were noted to be potential performing contractors that can be relied upon for timely project delivery within budgeted cost and predetermined quality and eligible to move to the next stage in the contractor selection process [32]. According to [33], prequalification exercise involved scope of work and contract type definition, and compiling the list of suitable contractors. Consequently, the entire contractors' prequalification process included development of selection criteria, gathering of data on contractors' capability and evaluating contractors' data. Applying the data to criteria, gathering more data (if necessary) and making the decision formed part of prequalification activities. In order to objectively determine the capability and competence of 
prospective bidders, [35] advocated creating equal opportunity and level plain ground for all bidders by consultants. More so, assessing contractors during prequalification exercise involves weighing contractors' abilities on the scale of some criteria determined by the decision makers [33]. Contractors' prequalification criteria, as revealed in previous studies, posses no standard number as it depends on client's and present project characteristics according to [7] and [34].

In line with standard practice, a number of research results confirmed that construction contractor can be chosen based on some criteria. Due to the enormity of these criteria, the work of $[9,33,35,36]$ summarised contractors' prequalification criteria into financial capacity, location of contractor's office (s) relative to project location, location of the project, capability for the type of work cost, size, and complexity of the project, as well as current commitment, technical capability, managerial capability, general information, past performance, health and safety records, experience and past performance. For virtually all construction works, similarity exists in their contractors' prequalification criteria. A comparison between [34] with [7, 9, 33, 35] established a disparity in contractors' prequalification criteria for building and civil engineering works. However, exceptional situation may arise in case of civil engineering project because of the peculiar characteristics of civil engineering work. As a result of this, [7], which revealed the contractors' prequalification criteria adopted for the parallel runway for Kingsford Smith Airport, indicated additional criteria to those mentioned in the previous researches. In this case, relevance of experience, size of firm, relationships (industrial relations, occupational health and safety, and claims and dispute history), past failures among others constituted additional contractors' prequalification criteria. These previous researches agreed that contractor selection can be premised on the listed prequalification criteria.

Contractor's performance during prequalification was said to depend on how best the documents/data/information provided met the requirements of each assessment criterion. However, whether a contractor met all the prequalification criteria was considered not be enough for decision making. Research result deemed it fit to investigate into the extent to which the requirements were met, bearing in mind that not all the criteria attract same degree of importance to the client [31]. It therefore supported apportioning of weighting to each prequalification criterion, suggesting that the most important criteria should carry highest weighting and low weighting attached to the least important criteria. The contribution of [9] and [33] indicated that construction project's time performance can be affected by contractors' prequalification criteria. In line with this view, literatures enumerated past performance, technical ability and management capability as dominant prequalification criteria affecting time performance of construction projects with emphasis on both price-related and non-price-related contractors' selection criteria [9].

\section{Research Methodology}

This study was designed to examine perceptions on the relevance of contractors' prequalification criteria to time performance of civil engineering project. Consequently, it adopted correlational approach designed to show whether there are some degree of relationship between two or more quantifiable variables according to [36]. This study therefore correlated contractors' prequalification criteria with time performance of civil engineering project. The opinion of construction professionals in both public and private organizations was sampled. These include professional Quantity Surveyors and Civil/Structural Engineers who were registered financial members of their respective professional association. Knowing that sampling technique involve determination of a sample from a larger population from which the nature of the larger population can be drawn, convenience sampling technique was adopted. This nonprobability sampling method involves collecting data from easily accessible and willing respondents [37]. The primary data used was collected through questionnaire survey, which presented seventy (70) contractors' prequalification subcriteria under nine (9) main contractors' prequalification criteria. The questionnaire allowed respondents to indicate their choice of option by scoring on a 5-point scale so as to obtain the ordinal data to determine the importance of each criterion. Regression analysis was employed to study the impact of criteria for contractors' prequalification on time performance of civil engineering project. According to [36], this non-parametric test technique allows a set of independent variables to be measured against a number of individual dependent variables for comparison purposes. It was adopted because of the ordinal nature of the data for this study and its capability to reveal the predicting power of independent variables and the pattern of prediction of the dependent variable. In this case, the independent variable with the highest standardized coefficient beta value, t-value and significance level, less than or equal to $5 \%(0.05)$ has significant impact on the dependent variable. The degree of association between the dependent variable (time) and independent variables (contractors' prequalification criteria) as well as the causal relationship between the independent variables was shown by the Karl Pearson correlation generated by the regression model.

\section{Results and Discussion}

\subsection{Relationship Between Contractors' Prequalification Criteria and Time Performance of Civil Engineering Project}

Table 1 revealed the relationship between civil engineering project time performance and criteria for prequalifying civil engineering contractors. At $\mathrm{r}<0.05$, contractor's general/background, technical ability, financial ability, management ability, reputation, past performance including health and safety, relationship, and environmental, sociopolitical criteria recorded positive relationship with time 
performance of civil engineering project. Despite this, contractor's reputation recorded highest relationship with time performance of civil engineering project $(\mathrm{r}=0.436)$, indicating that civil engineering contractor's reputation possessed higher influencing tendency on time performance of civil engineering project compared to other criteria for prequalifying civil engineering contractors. Civil engineering contractor's financial and management ability had their rvalue estimated at 0.367 and 0.335 respectively. It therefore had considerable positive relationship with time performance of civil engineering project. A positive relationship also existed between time performance of civil engineering project and civil engineering contractor's general/background and relationship at $\mathrm{r}=0.283$ and 0.257 respectively, meaning that they had remarkable influence on time performance of civil engineering project. A positive relationship existed between time performance of civil engineering project and contractor's technical ability, past performance, health and safety including environmental, socio-political criteria with $\mathrm{r}=0.159, \quad 0.177, \quad 0.199$ and 0.144 respectively. These considerably low values suggested they had little or no influence on time performance of civil engineering project.

Table 1. Correlation matrix between contractors' prequalification criteria and time performance of civil engineering project.

\begin{tabular}{|c|c|c|c|c|c|c|c|c|c|c|}
\hline & Time & $\begin{array}{l}\text { General/Back } \\
\text { ground }\end{array}$ & $\begin{array}{l}\text { Technical } \\
\text { ability }\end{array}$ & $\begin{array}{l}\text { Financial } \\
\text { ability }\end{array}$ & $\begin{array}{l}\text { Management } \\
\text { ability }\end{array}$ & Reputation & $\begin{array}{l}\text { Past } \\
\text { performance }\end{array}$ & $\begin{array}{l}\text { Health and } \\
\text { safety }\end{array}$ & Relationship & $\begin{array}{l}\text { Environmental, } \\
\text { Socio-Political }\end{array}$ \\
\hline Time & 1.000 & & & & & & & & & \\
\hline General/Background & .283 & 1.000 & & & & & & & & \\
\hline Technical ability & .159 & .495 & 1.000 & & & & & & & \\
\hline Financial ability & .367 & .566 & .375 & 1.000 & & & & & & \\
\hline Management ability & .335 & .413 & .600 & .572 & 1.000 & & & & & \\
\hline Reputation & .436 & .491 & .412 & .589 & .612 & 1.000 & & & & \\
\hline Health and safety & .199 & .447 & .350 & .527 & .499 & .587 & .636 & 1.000 & & \\
\hline Relationship & .257 & .441 & .436 & .546 & .473 & .585 & .664 & .643 & 1.000 & \\
\hline $\begin{array}{l}\text { Environmental, } \\
\text { Socio- Political }\end{array}$ & .144 & .420 & .319 & .523 & .352 & .437 & .592 & .566 & 679 & 1.000 \\
\hline
\end{tabular}

Table 1 also indicated that positive interrelationship existed between criteria for prequalifying civil engineering contractors while affecting time performance of civil engineering project. This study depicted that respondents agreed that contractors' prequalification criteria positively affect time performance of civil engineering project, but at varying degree. This aligned with the result in [9] where contractors' prequalification criteria were found to significantly affect time performance. The study indicated that reputation, financial ability and management capability emerged the top three contractors' prequalification criteria affecting time performance of civil engineering project. Going by this result, due importance was accorded reputation and financial ability because they proved to be essential instruments for timely completion of civil engineering project.

\subsection{Impact of Contractors' Prequalification Criteria on Time Performance of Civil Engineering Project}

Table 2 presented the impact and predicting power of criteria for prequalifying civil engineering contractors on time performance of civil engineering project. At $\mathrm{p} \leq 0.05$, civil engineering contractor's reputation polled highest standardized coefficient beta value $(0.430)$ and $t$-value $(t=3.862)$, signifying that civil engineering contractor's reputation made the strongest unique impact on time performance of civil engineering project. Civil engineering contractor's past performance ranked next to reputation with $\mathrm{t}=2.430, \mathrm{p}=0.16$ and standardized coefficient beta value of 0.290 . This indicated that civil engineering contractor's past performance also contributed uniquely to time performance of civil engineering project. At $\mathrm{p} \leq 0.05$, civil engineering contractor's general/background, technical ability, financial ability, management ability, and health and safety including relationship and environmental, social and political criteria had no significant impact on time performance of civil engineering project because their $\mathrm{p}$ values were greater than 0.05 . The adjusted $\mathrm{R}^{2}$ value was 0.226 , meaning that about $23 \%$ of time performance of civil engineering project was impacted upon by criteria for selecting civil engineering contractor.

Table 2. Impact of contractors' prequalification criteria on time performance of civil engineering project.

\begin{tabular}{llll}
\hline Variables & Standardized Coefficients Beta & t-value & p-value \\
\hline (Constant) & & 6.674 & .000 \\
General/Background & .084 & .879 & .381 \\
Technical ability & -.079 & -.800 & .425 \\
Financial ability & .173 & 1.642 & .103 \\
Management ability & .169 & 1.549 & .123 \\
Reputation & .430 & 3.862 & .000 \\
Past performance & -.290 & -2.430 & .016 \\
Health and safety & -.102 & -.980 & .329 \\
Relationship & .128 & 1.111 & .268 \\
Environmental, Social and Political & -.062 & -.590 & .556 \\
\hline
\end{tabular}


As a result of the outcome of this study, contractors' prequalification criteria affected time performance of civil engineering project as perceived by Quantity Surveyors and Civil/Structural Engineers. However, a consensus opinion revealed that reputation recorded highest degree of relationship with time performance of civil engineering project. This confirmed the view in [38] and [39], where reputation was found to be instrumental to winning contracts. This research showed that criteria for contractors prequalification had significant positive relationship with time performance of civil engineering project. A significant positive interrelationship existed between the criteria for contractor prequalification, although at varying degree. It was evident that time performance of civil engineering project was determined by criteria for contractor prequalification. Going by this result, the need for contractors' prequalification criteria to complement one another became important to ensuring a successful civil engineering project in terms of time target. By implication, the positive interrelationship that existed between the entire contractors' prequalification criteria, while affecting time performance of civil engineering project, established an agreement among the contractors' prequalification criteria. Therefore, meeting time target by civil engineering project needed the involvement of a number of contractors' prequalification criteria. Also, criteria for contractor prequalification impacted significantly on time performance of civil engineering project. This indicated that time performance of civil engineering project depended on adequacy of the criteria for prequalifying the contractor to handle the delivery of civil engineering project.

This study found that reputation and past performance emerged top two contractors' prequalification criteria impacting on time performance of civil engineering project contrary to past performance and technical ability established in [9]. Hence, the position of past performance in both cases indicated partial alignment with each other. This may stem from the fact that building and civil engineering projects constituted different arms of the construction industry. Despite this, it could be advanced that the result connoted similarity in their contractors' prequalification criteria which might dictate their influence on time performance. In similar manner, the emergence of reputation as the most influential contractors' prequalification criterion in terms of time performance of civil engineering project indicated a disagreement with the result in [9] which emphasized past performance. This showed that civil engineering project stakeholders' opinion in respect of the relevance of contractors' prequalification criteria to time performance differed from those of building project. This result can be traced to the characteristics and peculiar resource requirement difference existing between civil engineering and building projects. This study corroborated the finding in [40] which depicted that failure to complete project on schedule was detrimental to sustenance of reputation. Therefore, placing this result in tandem with [40] showed that timely completion of civil engineering project was imperative to building required reputation. This implied that a strong relationship existed between time performance of civil engineering project and contractors' reputation. Besides, the outcome of this research quite negated the result in [41]. Despite [41] placing construction projects on same platform, management capability emerged the criterion that impact most on time performance. It should be noted that [9] focused on building and housing construction projects while [41] based its research on construction projects. This signaled a kind of difference in their research areas. The area of concentration in [41], which could be viewed to include civil engineering project, was obviously more encompassing compared to that in [9], yet share same view by rating management capability high. Similarly, the research effort revealed in [42] confirmed that management capability impacted most on time performance of construction project in line with the result in [41]. It solicited that due recognition be accorded management capability having stressed its importance to achieving timely completed project. In spite of management ability ranking among the top four contractors' prequalification criteria influencing time performance of civil engineering project, it is essential to submit that its p-value in this study, falls outside $\leq 0.05$ range. This showed that contractors' management capability was insignificant to achieving time performance in respect of civil engineering project. Thus indicated that time performance of civil engineering project was independent of contractors' management ability. Hence, this study believed that relying on contractors' managerial capability in respect of civil engineering project could lead to failure as far as time performance is concerned contrary to the opinions expressed in $[41,42]$.

\section{Conclusion and Recommendation}

This study had been able to reflect perceptions on the relevance of contractors' prequalification criteria to time performance of civil engineering project. Criteria for contractors' prequalification were absolutely relevant to and influential on time performance of civil engineering project. Despite this, contractors' prequalification criteria commanded varying degree of relevance to time performance of civil engineering project. Therefore, the importance attached to time as far as civil engineering project is concerned would dictate the criteria for contractors' prequalification to be adopted. This would guide against making the choice of wrong set of contractors' prequalification criteria especially where other project performance measurement parameters were involved. Also, contractors' prequalification criteria complement one another while affecting time performance of civil engineering project. In view of this, no single contractors' prequalification criterion would produce expected timely completed civil engineering project without contribution from other prequalification criteria. This evidently established that no contractors' prequalification criterion possessed adequate 
quality to yield expected result. Ability of contractors' prequalification criteria to predict time performance of civil engineering project varied. Therefore, contractor's reputation and past performance impacted significantly on time performance of civil engineering project. Hence, placing time on same platform with other project performance indicators during contractor prequalification process could lead to nonperforming civil engineering project in terms of time target. The choice of contractor for civil engineering project to meet expected time target should not be based on sole prequalification criterion because of the need to make up for the limitation and inadequacies that might be associated with the most relevant or influential prequalification criterion. This would be achieved by involving other criteria under consideration. Civil engineering project clients and consultants should concentrate on the contractors' prequalification criteria that impacted most on time performance during contractor prequalification process for civil engineering project. In view of this, prioritising reputation and past performance became highly essential while other prequalification criteria, such as financial ability, management ability, relationship, health and safety, general/background, technical ability and environmental, socio-political criteria should play complementary role in order to achieve expected result.

\section{References}

[1] Ojo, S. O. (2009). Benchmarking the performance of construction procurement methods against selection criteria Nigeria. Journal of Civil Engineering Dimension September, 2009.

[2] Civil Contractors federation (2010). Resourcing the future national resources sector employment task force discussion: 115.

[3] Pierre, D (2003, April 4-6). Risk in civil engineering from natural to man-made hazards. France-Stanford conference on risk issues in contemporary science and engineering; Stanford: $1-14$.

[4] Lake, L. (2008). Civil Engineering; Microsoft Encarta.

[5] Oforeh, E. C. (2006). The Cost Management of Heavy Capital Projects. Vol. 1; Construction and Management. First Edition. Cosines Nig. Limited. 2006: 1-10.

[6] Barbara, J. J. (2004). Construction management jump start. London: San Francisco: 2-140.

[7] Salama, M; Abd, E. A; EL, S. H and El, S. A (2006, September 4-6). Investigating the Criteria for Contractors Selection and Bid Evaluation in Egypt. Conference proceeding of $22^{\text {nd }}$ Association of Researchers in Construction Management. Birmingham, UK: 531-540.

[8] Ogunsemi D. R. and Aje I. O. (2005). A model for contractors Selection in Nigeria. The Quantity Surveyor 50 (1) 3-7

[9] Puoy, P (2011). Contractor prequalification criteria, tendering criteria, and tendering procedure in Cambodia building and housing construction projects. Journal of professional project management education.
[10] Zavadskas, E. K; Vilutiene, T; Turskis, Z and Tamosaitiene, J (2010). Contractor Selection for Construction Works by Applying SAW-G and TOPSIS Grey Techniques and Management.

[11] Masamintsu, O; Khairuddin, A. R; Toshihiko, O. and Kiyoshi, K. (2003, August 18-19). A Comparative study on the standard forms of contract in Malaysia and Japan with specific reference to variation procedures. A paper presentation at the 2003 Quantity Surveyors National Conference at Sheraton Hotels and Tours, SubangJaya, Selengor, Malaysia.

[12] Slobodan, M (2006). Civil engineering projects realization management. Journal of Architecture and Civil Engineering 4 (2).

[13] Tran, M. T (2009). Project time and cost performance in water supply pipeline construction in Dong Nai Province, Vietnam. A system dynamics approach. Professional project management education.

[14] Ng, W. S. and Aminah, M. Y. (2006, September, 5-6). The selection factors of design and build procurement method; A literature visit; Conference proceedings of the $6^{\text {th }}$ Asianpacific structural engineering and construction (APSEC 2006), Kuala Lumpur, Malaysia.

[15] Rathsayam, T (2009). Factors affecting project delivery time delays and cost overruns of project development at the Royal irrigation department of Thaitan. Professional project management education.

[16] Azian, S., and Ismail, R. (2010). The performance measurement of construction projects managed by ISOcertified contractors in Malaysia. Journal of retail and leisure property 9: 25-35.

[17] Othman, A. A; Torraance, J. V. and Hamid, M. A. (2006). Factors influencing the construction of time of civil engineering projects in Malaysia. Journal of Engineering, Construction and Architectural Management, 13 (5): 481-501.

[18] Khamidi, F. M; Khan, A. W and Idrus, A. (2011). The cost monitoring of construction projects through earned value analysis. International conference in Economics and Finance Research IPEDR 4 IACSIT Press, Singapore.

[19] Ng, T. S. and Skitmore, M. R. and Lam, K. C and Poon, A. W. C (2004). Demotivating factors influencing the productivity of civil engineering projects. International Journal of Project Management 22 (2): 139-146.

[20] Arazi, I., Mahmoud, S., and Mohamad, H. (2011). Decision criteria for selecting main contractors in Malaysia. Research journal of applied engineering and technology 3 (12): 13581365

[21] Udechukwu, E. C, and Iyagba, A. O (2008). Comparative Analysis of Construction Senarios in Japan and Nigeria. The Quantity Surveyor 55: 28-37.

[22] Nwosu, C. C. C. (2003). High Cost of Building in Nigeria. The Quantity Surveyor 44 (3).

[23] Onwusonye, S. I. J. (2002). The Role of Client's in-house Professional in Capital Project Procurement and Delivery. The Quantity Surveyor. 38 (1).

[24] Nagarajan, K. K. (2012). Project management ( $6^{\text {th }}$ edition): New Age International Publishers. 
[25] Chitkara, K. K. (2011). Project management; Planning, scheduling and controlling ( $2^{\text {nd }}$ edition). New Delhi: Tata Mcgraw Hill.

[26] Salter, A and Torbett, R (2003). Innovation and performance in engineering design. Journal of Construction management and economics, 21

[27] Odeh, A. M.; and Battaineh, H. T. (2002). Causes of Construction Delays: Traditional Contracts. International journal of project management. 20 (1).

[28] Peek, B. V. (2006). Construction management: Choosing the best project delivery method; Construction management association of America. Retrieved from. http//www.emaanet.org/

[29] Adnan, E., Sherif, M., and Saleh, M. (2009). Factors affecting the performance of construction projects in the Gaza strip. Journal of civil engineering and management 15 (3).

[30] Ajayi, O. M., and Ogunsanmi, O. E. (2012). Decision maker's perceptions on contractor prequalification criteria. Journal of contemporary research in business 4 (6): 174-180.

[31] Xiaohong, H (2011). An analysis of the selection of project contractor in the construction management process. International journal of business and management, 6 (3): 184189.

[32] Queensland (2007). Contractor prequalification criteria; Service risk assessment, Queensland government: 1-10.

[33] Aje, I. (2012). The impact of contractors' prequalification on construction project delivery in Nigeria. Journal of engineering, construction and architectural management 19 (2): $159-171$
[34] Ng, T. S. and Skitmore, M. R. (2001). Contractor Selection Criteria: A cost Benefit Analysis. Journal of Engineering Management 48 (1).

[35] Nguyen, D. H. C. (2011). Owners tendering strategy to obtain a qualified contractor. Professional project management education.

[36] Kothari, C. R. (2004). Research methodology; Methods and techniques. New age international publishers.

[37] Charles, T. and Fen, Y. (2007). Mixed methods sampling: A typology with examples. Journal of mixed methods research, $1(1)$.

[38] Fuziah, I., Muzani, M., and Fara, D. (2006). Risk factors of contractors' corporate reputation, $I C C I$.

[39] Jeffrey, V; Emica, C; Pierluigi, C and Giancarlos, S. (2012). Reputation and entry. Retrieved from http://www.reputation_and_entry_may28pdf

[40] Msafiri, A. S. (2015). An investigation into factors causing delays in road construction projects in Kenya. American Journal of Civil Engineering 3 (3): 51-63.

[41] Aje, I. O., Odusami, K. T., and Ogunsemi, D. R. (2009). The impact of contractors' management capability on cost and time performance of construction projects in Nigeria. Journal of financial management of property and construction 14 (2): 171-187.

[42] Pooria, R., Muhd, Z. A. M., Mahmoud, B., and Farzan, G. (2015). Contractor selection at prequalification stage: current evaluation and shortcomings. Jurnal Teknologi (Sciences \& Engineering) 77 (16): 81-89. 